\title{
THE ROLE OF ART IN SCIENCE
}

\author{
Taeke M. de JONG
}

Received: 11.12.2008, Final Text: 02.04.2010

Keywords: art; design study; empirical research; context-sensitivity; methodology; causal thinking; conditional thinking; recognition; imagination.
The study of architectural, urban and related technical design struggles with its context sensitivity hampering a contextless and categorybound scientific generalization. Many concepts describing design issues are different from the categories and variables of empirical science. Incomparable categories such as 'strong', 'useful' and 'beautiful' have to be combined in design. These combinations cannot be expressed in a 'statement-based' scientific discourse. Design annoyingly jumps through its sentences and statements that unroll primarily in time. Images are indispensible in communicating the spatial diversity observed or intended. Materializing spaces allows contradictions, but it is not irrational. It only transcends the categories of verbal language and classical logic. It uses the sources of imagination in a rational, but not always in a logical, and certainly not in a predictable way. Art shifts the boundaries of imagination. And imagination is the foundation of both science and design. Art transcends categories into new imaginations. New imaginations are required to find new categories as components of a composition. Design restricts itself to realizable imaginations. Its boundary is 'possibility', whereas science restricts itself to 'probability'.

Science is a human design, and design is an art. So, even science is an art, a human creation. After all, probability supposes possibility and that supposes imagination. Imaginations and designed instruments often have preceded scientific progress. Design is not a part of science, but science is a part of design. It is in particular a part of the realization of a design. That shows the advantage of a scientific education for designers. It makes them less vulnerable in the company of specialists. A design concept will weigh up and integrate advice from the specialists. And these advices are often contradictory. Diverging specializations result in an archipelago of sciences, no longer criticizing each other. That is why science falls in the public's esteem. But, here is still a demand for imagination. That is the role of art and design. 
The public imagination fails in solving actual problems. It fails by global homogenization of culture, its everywhere generalized solutions. It fails by a decreasing awareness of real bio-diversity. It fails by a lack of awareness of the combinatory explosion of possibilities imagination can produce. Design should explore the improbable possibilities. It should shift incomparable categories just as our senses combine different sensory impressions. That is the foundation of concept formation. It integrates the experience of moving your body into object constancies while the boundaries are shifting. These new objects may become the different components and details of a design composition. And every level of scale has its own composition causing an interesting tension if it does not break down into chaotic incoherence.

The legend of a drawing is the key of the composition, its vocabulary. It designates the components of the composition and its characteristic, crucial, connecting and marking details. To explore our possibilities, to extend our freedom of choice, we have to break down the limitations of our imagination, increasingly bounded in cliché's by the mass media. We have to study the hidden suppositions of our imagination to find improbable possibilities. Since science is broken up into specialisms, hiding themselves in subcultures, paradigms and jargon, art and design now have a task in science.

\section{INTRODUCTION}

\section{Architecture at a University}

At universities of technology around the world, Faculties of Architecture struggle to justify their research and study in scientific terms. Some of the experience gained on that battlefield may be of use in clarifying art's role in relation to science. About once a decade in Delft, the question of the scientific justification of Architecture culminates in a debate about the role of mathematics in its education. 'Mathematics is the basic language of technology!' exclaim some. The academic title 'ingenieur' would be devalued without a proper grounding in mathematics!' maintain others. During my career at Delft University as a student in Urban Design and as a teacher in Ecology, I have witnessed the introduction of mathematics courses taught by the Faculty of Mathematics into the Faculty of Architecture on three occasions, only to be followed by its gradual, silent removal within five years. 'It's useless for architecture! You never use it in practice! It takes up too much time!' teachers of the Faculty (who have no such background in mathematics themselves) have complained.

\section{Context Sensitivity}

The deeper background to that debate is methodology. Teaching students to find convincing ways to study and justify architectural, urban and related technical design is something different to teaching how to execute empirical research. Empirical research is based on clear (and isolated) problem statements and produces 'ceteris paribus' solutions. Environmental designs for the long term, meanwhile, are 'ceteris non paribus' case studies. They are actually meant to change the local conditions of human action at many levels of scale. Thus, problems and solutions even partial ones- for a particular and unique spatial context are difficult to generalise for use in other contexts without modification. Buildings, neighbourhoods or towns are more sensitive to governmental, managerial, 
Figure 1. Ways to study.

Figure 2. A common view of scientists: the opposition of art and science (Voordt, 2002).
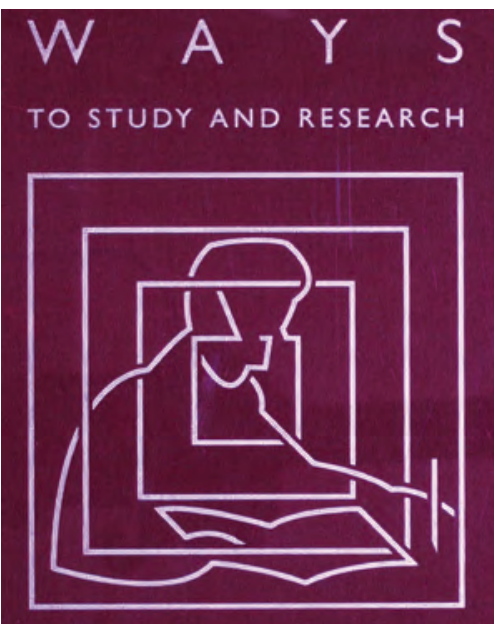

URBAN, ARCHITECTURAL AND TECHNICAL DESIGN

EDITED BY TIM. DE JONG AND D.J.M. VAN DER VOORDT cultural, economic, technical, ecological and spatial contexts at many levels of scale than any other kind of design taught at a university of technology.

\section{Other Categories Describing Design Issues}

Modelling any part of the design concept therefore, means that many external variables have to be taken into account apart from the internal ones that shape architecture. Every assignment is a 'wicked problem' with many vague aims and problems stemming from many local stakeholders and specialists, always varying in the composition of any installed building team. They can even change their priorities when confronted with a first design concept. So, problem isolation (as demanded by empirical research) is the end of any design career with the ambition to integrate categories that no empirical science can yet cover into a convincing concept that is sensitive to its context. It seems that there is something missing from the accepted scientific categories to be fully useful in the field of Architectural, Urban and related Technical design.

\section{Methodology to Make Use of Each Other's Progress}

I have also twice witnessed the establishment of a methodology committee for the Faculty of Architecture (in 1990 and 2000). I had the honour to be the secretary of both, working with a real empirical scientist, Theo van der Voordt, with a different view (Figure 2). I edited a book (Jong, 2002) to summarise the conclusions of both committees and present examples of empirical research and design-related study. Study is a useful English word which can be used to include both the narrower categories of research and design-related study. That book reported on contemporary ways to study and research by 48 authors from our Faculty. In doing so, it led the methodology debate for 5 years. Moreover, it temporarily succeeded in convincing the other faculties that Architecture has a scientific basis and ambition, even though that basis may still be primitive. The complexity of the subject means that many questions remain open, but the book produced a temporary scientific justification of architecture at a university. It was integrated into all educational phases during that period. However, its influence has since diminished. Not everybody recognised their particular way of studying in the book. Not many took the time to read all 57 chapters over 550 large pages with 600 images, schemes and tables, 600 references to literature and 10,000 key words. So, not many became aware of the methods of their colleagues, or realised that they were not the first ones to invent the way of studying that they were practising. Over five years, many creative newcomers started to invent the wheel anew and there was little of the accumulation or scientific progress based on mutual fraternal criticism that I had hoped to receive after publication.

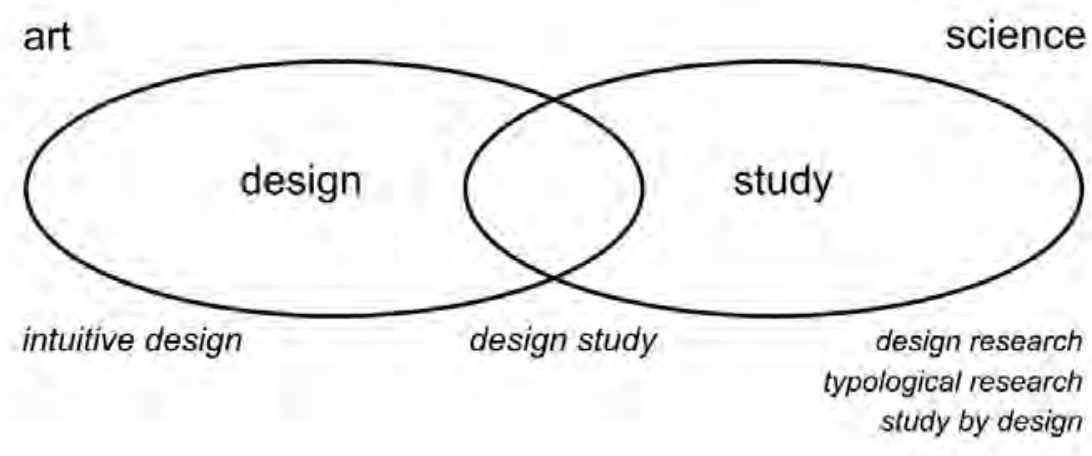




\section{Scientific Justification}

The question of scientific justification will also emerge if a more extended practice of Art enters a university like Art Science in Leiden. That entry seems to indicate that art can be part of science. Here, however, I would like to demonstrate the opposite: that science is a part of art. Art is not science, but science is an art. Science is based, tacitly, on the power of imagination. Art does not require science, then, but science may need art as a source of imagination. The role of science for art is limited, but art has a primary role for science. Why? To question its limitations, suppositions, categorisations and generalisations continuously, and to stretch its imagination of reality. Reality is more than truth or probability. To explain that, I would like to start with the more simple relationship between empirical research and technical design. Extrapolating that discussion may provide useful material with which to justify the presence of art at a university.

\section{SCIENCE'S TACIT ASSUMPTION OF DESIGN}

\section{Probability Supposes Possibility}

The difference between empirical research and technical design is, essentially, the difference between exploring what is probable and what is possible in the future. To look more closely at the difference between probable and possible futures before we descend into modal logic, we can conclude, quite simply, that anything probable is by definition possible, but not the reverse.

This means, then, that there are improbable possibilities. The probable ones can be predicted and explored using the usual means of empirical research simply because they are probable. But how can we explore improbable possibilities? That is precisely the role of design. A designer imagines improbable possibilities that do not yet exist. If designs were probable, they would be predictions and not designs. Designs are not what is 'true' or 'probable', but what is 'imaginable' and 'possible'. Empirical science aims at truth, or at least probability, and from that viewpoint a designer is a liar. Design therefore cannot be an empirical science.

\section{Design Uses Empirical Results but it Produces Something Else}

All this does not mean that designers do not make use of the results of empirical research. Probability is a subset of possibility, after all. It simply means that it is not their responsibility to deliver such results. Their core business is to develop unlikely possibilities. The predictable elements of design are delivered through empirical research. Designers choose from these and use them on location, balancing them in a context-sensitive

Figure 3. The task of empirical research.

Figure 4. The task of technical design.

Figure 5. The task of art.
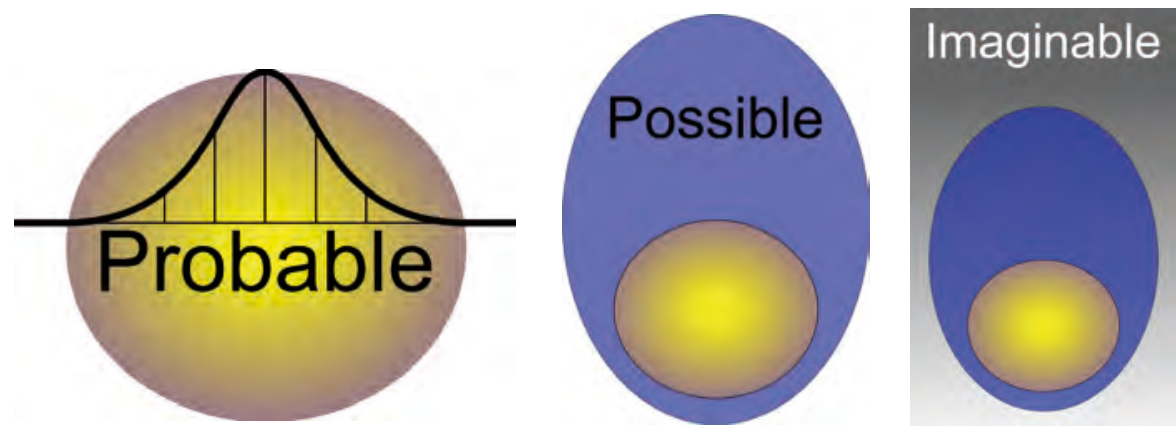
Figure 6. Desirable futures which determine sets of problems and aims, which then may change in the light of new possibilities.
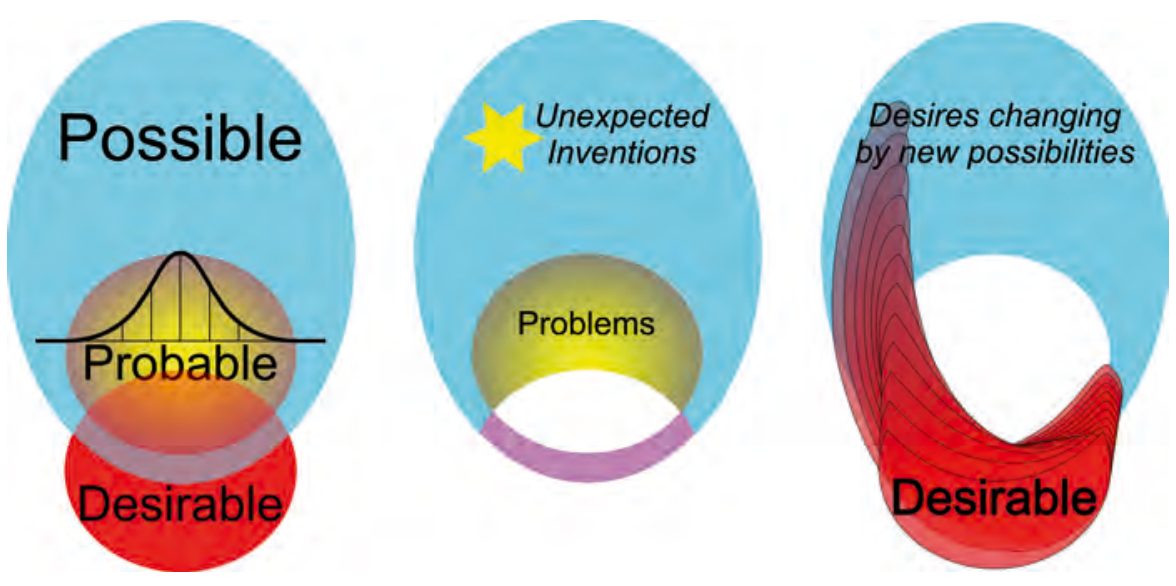

composition using improbable combinations, components and details to create new possibilities. The work of designers does not involve making predictions based on causal suppositions (hypotheses), as empirical scientists do. It cannot be, then, that the most suitable way of educating designers is drawing conclusions on causal relationships from statistical evidence and probability calculus. However, if they do not know how those kinds of empirical conclusions are reached, designers will be vulnerable within a team of specialists which is working with these generally accepted scientific methods. They must therefore study the methods of empirical research to be able to criticise the results of empirical generalisations within the specific context in which they are working. That critical faculty is needed to weigh up the often contradictory empirical advice that is issued by numerous empirically educated specialists in a planning team which needs to be integrated into a context sensitive composition. Today, it is that criticism between empirical specialisms that is failing to provide an effective screening mechanism for scientific proposals.

\section{Science Supposes Design}

However, science itself is a conscious human creation. And a conscious human creation presupposes design. So, science supposes design (imaginability - the capacity to imagine what is possible and / or desirable). Art presupposes imaginability as such, but imaginability is actually required in any conscious practice.

For example, policy supposes desirability, as far as desires of a political programme_are imaginable and possible. Imaginability, desirability, possibility and probability are different modes of practice and reasoning. In design education and practice, these appear as different modal futures which must be differentiated properly. That differentiation will identify the problems and aims that are motivating a given activity. Probable futures which are not desirable produce a set of problems for study and design, and desirable futures being not probable produce a set of aims.

\section{Imaginations and Designed Instruments Precede Scientific Progress}

Anything true or probable is, by definition, also possible and imaginable. If the content of a drawing or a text is not imaginable or possible, it cannot be probable, let alone true. It cannot be the object of science before it is made imaginable. Leonardo da Vinci and Vesalius had to draw our inner organs accurately before Harvey could even begin to imagine how our blood circulates. 


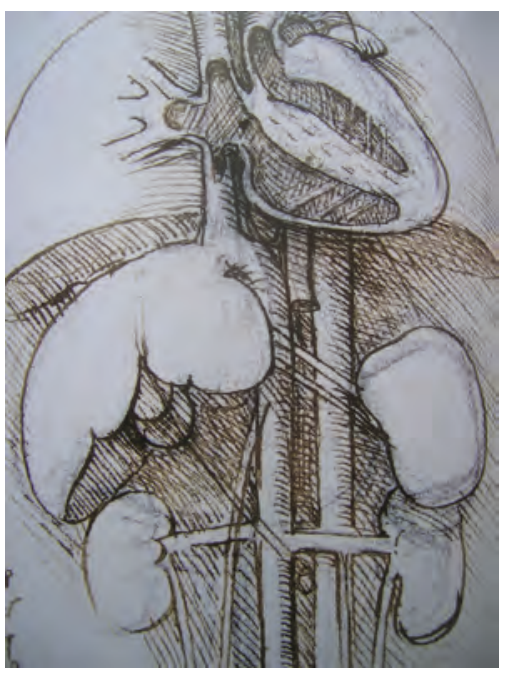

Figure 7. The heart by Leonardo da Vinci in 1509. (Windsor Castle, Royal Library RL19112r.)

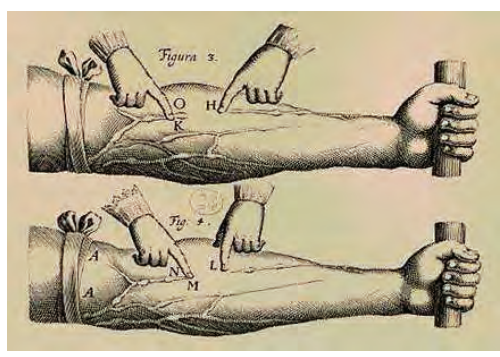

Figure 8. The proof of blood circulation by Harvey in 1628 (Harvey (1628) Exercitatio Anatomica de Motu Cordis et Sanguinis in Animalibus.)
The telescope had to be designed and realised before Galileo could see the moons of Venus and imagine that they were continuously 'falling' in a circular movement, confirming Copernicus' assumptions and Kepler's measurements. The steam engine had to be designed and realised before Clausius and Boltzmann could develop thermodynamics a century later, imagining entropy as the key to its efficiency.

\section{Science is not Necessarily Part of Design but of the Realisation of Design}

Imaginability and possibility are, then, preconditions for science. Design is supposed in science, though it is often a hidden supposition. Scientists themselves talk of the design of a research programme, the design of a research tool such as a telescope, a microscope, a cyclotron, an inquiry or even algorithms, and the design of an organisation. So, it is misguided to ask whether design can be part of science (and design education part of scientific education). What we should be asking is whether science (as a subset of design) should always be part of design. If not, the following question is whether there is still a role for studying design beyond empirical science (probability study, research). If so, many further questions emerge about that role. But let us first answer the question of whether science should always be part of design.

If we look at the remarkable results of designers who have had no scientific training, we might be inclined to say that science does not always need to be a part of design. However, even designers who pay no apparent heed to scientific concerns make implicit use of empirical experience from past precedents in order to prove the possibility of design principles: types, concepts, models and programmes. What is more, in materialising and realising their designs these days, they will use other people's scientific findings ('this kind of brick will hold the required pressure,' for example). So, our final conclusion must be that the results of empirical science are always part of realising designs, but not necessarily a part of design itself.

\section{The Advantages of a Scientific Education for Designers}

A design education does not, then, always need a scientific input. Scientists defend that input on the basis of the many avoidable design mistakes that have become apparent in designs after their realisation. However, in practice many empirically educated specialists will evaluate the design at many stages during their development, filtering out such mistakes before realisation. Given that the designer will be constantly on the receiving end of specialist empirical advice, the role of the designer becomes something else. Education can never replicate all the advice that a specialist will contribute in practice. Avoiding mistakes at the very beginning of the design process is thus not a strong argument for science in design education. A better argument would be that a designer with no scientific experience will be in a vulnerable position when surrounded by all those specialists. He or she would not be in a position to rebut their arguments or ask the right questions about their hidden assumptions.

\section{Natura Artis Magistra}

However, a scientific training may give designers another advantage. Science activates our senses. It forces our imagination into areas that are not accessible to the naked eye, the naked ear or to our other senses, as they are used in everyday life. The exploration of the microscopic and the macroscopic reveals phenomena which would have been difficult for us to imagine previously. However rich our human imagination may be, it is 
poor compared to reality. Biology, in particular is a realm that continues to astound us. 'How is that possible? Could you imagine?' we exclaim. Many innovations nowadays are based on the incredible abilities of micro organisms, plants and animals. But no technical university could ever have designed a mosquito, for example: its abilities in flight, in coordinating and synchronising its functions, in adapting to its environment, in reproducing its concept in its offspring, but with many fractional modifications in order to perpetuate the species and change according to environmental circumstances - all of this is still inconceivable, and may lead some to suggest the possibility of 'intelligent design'. Our imagination of extraterrestrial life in science fiction, meanwhile, is still bounded by representations of what we know - terrifyingly enlarged insects or mutants of humans. Even when designing toys, such as 'transformers', we apparently need something from everyday life to latch on to, to prevent our impressions from falling into chaos. On the other hand, if we recognise too much we will lapse into boredom. Our neural system, it seems, needs stimulation in just the right quantity - not too little and not too much. Perhaps this is the dynamic balance between recognition and surprise that we call beauty.

\section{A Design Concept will Weigh up and Integrate Advice from the Specialists}

Education cannot provide all the specialist knowledge needed for the evaluation of every student's design. In practice, a designer confronted with many such scientific evaluations will gradually, through experience, become more aware of design limits. To avoid mistakes, he or she will apply ever stricter limits when formulating design concepts. Without a scientific background, the designer will have to accept the specialists' recommendations without questions or objections, but a designer with some scientific understanding will be able to put this advice into the perspective of a specific context. He or she can weigh up the relative merits of various recommendations in relation to one another and as well as in relation to the architectural quality to be reached.

\section{Diverging Specialisations Result in an Archipelago of Sciences}

Perhaps a designer will even come to recognise the same structure in the recommendation he or she receives, combining different disciplines into broader categories that are unknown in science and difficult to formulate. That broader interdisciplinary understanding through context-sensitive design is urgently needed in science itself. Design has a message in the university context. Science is increasingly fragmenting into its different specialisations, which are becoming increasingly inaccessible due to their collective assumptions, their jargon, their instruments (paradigm), their specialists' journals. These go uncriticised externally due to their growing monopoly. Their standards are accepted without that criticism by policy makers, who are convinced of their own generalisations. Specialists become less and less aware of context, of the object of each others' study, of their limitations. Through a lack of context awareness, transfixed by mathematical evidence, generalisations based on hidden suppositions, policy makers and designers receive contradictory recommendations from these specialists. So, they choose the specialists who support their opinions and decisions. Whatever decision is made, a specialist can be found to support it. 


\section{The Fall of Science in the Public's Esteem}

Television viewers, who pay their taxes for education and policies on, for example, health and safety or the environment which are based on 'scientific research', today witness debates between professors, hired by opinion makers, making contradictory recommendations. Previous policies, enacted at great expense to the public purse, are called into question. 'What have we paid for?' ask the public. They feel 'there is something rotten in the State of Science', which is has been divided into parts that are increasingly protected from external critics. Universities are no longer universal but specialised, struggling for survival and locked in mutual competition. Specialised authorities, or 'peers' censor scientific publications in expensive specialised periodicals. Three centuries of debate on the topic of authority called 'Enlightenment' seem to fade away. We have returned to mediaeval times. Authority is a scientific argument again. Audiences view debates between authorities without distinction, whether those authorities are scientists, politicians or rock stars. Rather than complex arguments, they prefer to accept the common sense that stems from their personal experience. What are they going to pay taxes for in the future? In any case, people are willing to pay for identity, uniqueness, imagination, possibility, and design. Designs sell better than scientific articles. But, these also incorporate the results of science.

\section{A Demand for Imagination}

A design education remains attractive for students with imagination. And imagination is a prerequisite for both science and policy. Architectural design and urban design compel their practitioners to include managerial, cultural, economic, technological, ecological and spatial futures on different levels of scale, including but surpassing the everyday scale. It is for this reason that these disciplines should include science within their curricula to become truly universal, open to the depths of many specialisations, but broad, sensitive to context, and putting specialisation into perspective through the ability to criticise coherently. Design extends science from what is probable alone, to include what is possible and imaginable. Design offers hope in a world of depressing predictions. In their possible worlds, designers make room for desires that no one else could have imagined before they were designed. Policy makers are freed from limiting suppositions about probable futures and the possible futures imagined by design open up new opportunities. The task of design education is to restore the university, and free it from the mere accountancy of facts which is not up to the task of creating the new, unexpected possibilities which we now need.

\section{THE ROLE OF ART}

\section{A Failure of the Imagination}

I am disappointed by the current ability of humans to imagine the unfamiliar. Students cannot imagine concepts unless they are presented in an easy-to-digest formula along with images, jokes and anecdotes to open up their minds, which are filled with the concerns of contemporary everyday life. These days, lectures have to compete with the media to hold the attention of the students, and that takes time, time which could be spent on the many other subjects you would like to present.

Architects, under pressure from clients to complete projects within a tight timeframe, hastily copy-paste former solutions from their CAD archives 
onto boring façades and call this 'architectural clarity', or even 'personal style'. They compete for space in architectural journals edited by failed designers, who get to determine what architecture is. It is only once you are famous that you may be allowed to accomplish something more unusual, and after that everyone else will begin imitating you. Building contractors shun unusual solutions unless they have been accepted in the media, while specialists force you to ignore your most extravagant fantasies, because there are no empirical data on them.

Scientists create ever more categories (variables) in the hope of generalising the many particular phenomena that remain to be defined. To cope with all this conceptual variety, they divide themselves into an increasing number of specialisms, which consume ever more time and resources to explain these phenomena. But disciplinary limitations mean that they lose a feeling for practical context. In doing so, they lose their understanding of other disciplines and no longer benefit from the interdisciplinary criticism which is required to solve the increasing number of contradictions that we face in a context-sensitive reality.

The man in the street watches television hour after hour, day after day, year after year, in order to be fed the images prescribed for a 'Hollywood lifestyle' which he is required to emulate in his clothes, homes, workplaces and holidays. Follow the idols to be popular before your friends do! Trendwatchers predict the colours you will need to be seen in next year.

\section{Global Homogenisation}

If you want to escape from this predictable, increasingly boring environment, you could always take a package tour to a foreign land. After you arrive at the last remaining boundaries of global culture to see the dances of tribes untouched by the outside world, you will meet the same tribesmen later in the disco, wearing their Nikes. Your hotel will conform to international standards of comfort, producing total homogeneity wherever you travel. You will have to feel at home after all, to recover from all those unfamiliar impressions. But what is 'home', if home is everywhere?

In a rapidly dwindling number of destinations, you may discover that poverty has more faces than affluence, but it is actually frightening to face up to the responsibilities you have just tried to escape for a while. Fortunately, however, visiting these places will contribute to local wealth and help the country to adapt to global norms. Why bother if it is convenient and you cannot imagine anything else than a Hollywood civilization anymore? Within that declining number of really different references for living, details count. Cars are increasingly standardised. A minor difference is enough to distinguish your identity, as long as you buy it in time.

\section{Decreasing Awareness of Real Diversity}

As a teacher of ecology, I am inclined to study nature. To understand ecological literature, with its extensive Latin nomenclature, I try to name the plants I see on my way to work. After many years, there is still only a limited number of species that I can recognise properly. Take the many species of grass alone. How on earth could I cope with all the mosses, toadstools, insects or birds that I see? I am increasingly bewildered by a diversity that no generalising science can ever grasp. And what you cannot imagine, you exclude from your realm of responsibility. Who cares? It is the most convenient attitude to take. At a global level, now we are 
currently losing one thousand species every year and gaining just one, according to the average rate of evolution. This is extremely difficult to imagine, so we exclude it from our awareness. Our daily life is complex enough. We favour politicians who promise to reduce the complexity of our obligations, and then we forget what they promised due to the stress of our busy lives and the increasing number of choices we are faced with. Our globalising culture forces us to make choices every second. But the question is whether the alternatives we are presented with are really different. We lose ourselves while deliberating over insignificant details. The difference between two species of grass is much more significant than the difference between two brands of coffee. We are losing our sense of proportion.

\section{The Combinatory Explosion of Possibility}

The real diversity of nature may be inconceivable, but it is only one of the very many possible worlds. If we limit our design possibilities to a flat surface 16 pixels wide by 16 pixels tall and 256 colours (an old fashioned Windows-icon), the number of possible combinations is $256^{256}$.

The number of atoms in the universe is estimated at $10^{110}$. That is less, inconceivably less, than $256^{256}$. And when making any piece of art we have more than 16 pixels by 16 filled with 256 colours to work with. However, we are imprisoned by the limitations of the categories we inherit. Science is imprisoned by the verbal categories that determine any set. Even applied mathematics has to obey these categories distinguishing variables. But images or pieces of music do not count for much in science, because they surpass the laws of formal logic. They throw up contradictions and the boundaries between the usual categories are ill-defined. They do not exclude possibilities that scientific specialists like to avoid. They allow ambiguity, referring unexpectedly to other domains. How often do I fail to find the words to express my thoughts? And as a result, I forget them, or force them into the categories of the culture in which I live, or into the language in which I have learned to express myself. Sometimes I draw, act in the theatre or sing, but I will never know whether the spectator or listener shares my thoughts. Even using verbal expressions, I am not sure whether the audience shares the categories supposed in the logic of language. Sometimes I look for a poetic means by which to express scientifically incomparable categories to reframe my world of thought. The word poetry has its origins in the Greek word for the art of making things.

\section{Exploring the Incomparable}

Architecture needs to join three incomparable categories in its designs: strength, utility and grace. These categories had already been identified by Vitruvius at the time of the birth of Jesus Christ. The categories of strength, utility and grace have since been cited very often to formulate architectural quality very often and in many forms (for example, sustainability, functionality, image quality). However, nothing can be stronger than it is useful, more useful than it is beautiful, or more beautiful than it is strong, other than in a poetical sense. These categories, then, remain impossible to compare in rational terms. Design has to transgress incomparable categories through art. There we have it: the task of art is to transgress the usual categories of the imagination. Impressionism taught us that human bodies do not have the homogeneous colour of human bodies, as taught by the academies. Art science should learn and teach that a 'theory of everything' will never capture the diversity of reality. Then the question will emerge of how to capture what is possible or even imaginable. 
But let us start with reality, since science still cannot capture even that fully.

\section{Combining Different Sensory Impressions}

Experiments with babies, reported by Piaget and Inhelder (1947), have captured my imagination ever since I first read about them because of the practical and design implications of the idea. First, they gave the children an object to feel by touching behind a screen, making sure they could not see it. Then they showed the children the same object, making sure they could not touch it. Piaget and Inhelder questioned at what age the children would combine these two totally different and incomparable sensory impressions into one concept. This appeared to happen at an average age of one-and-a-half years old. These conclusions were later criticised (in fact, it happens earlier) but the idea has remained the same.

\section{Concept Formation}

Combining various sensory impressions synaesthetically into a single concept of the object involved is more than a conditional Pavlov-reflex. Preparing your digestive system to digest when a bell rings does not yet mean that you can imagine it as a concept. A concept means that if you feel the object without seeing it, you can visualise the object without seeing it. It is the very start of logical operations such as 'not', 'or', 'if ... then'. It explains the fascination of young children for the game of peek-a-boo or hide-and-seek: the mother hides and calls the child. The child can hear her voice, but cannot see her and goes looking for her in order to complete its sensory concept of the mother.

\section{Moving Experience}

In later investigations, Piaget and Inhelder emphasised the important role of the motor ability in imaginative capacity and learning. You can change your visual impression by moving physically. This possibility causes children to experiment continuously. I remember my niece crying at her first birthday party. Grandma put her on her lap, saying 'Quiet my darling, quiet!' But she continued to cry and kick her legs. I had been reading Piaget and said: 'Give her to me'. Grandma handed me the child and I helped her kicking legs to move her body up and down to see my face alternating with the background. She immediately started laughing! Grandma, somewhat embarrassed, thought she loved me more than her, but I explained her that the baby was experiencing parallax: changing object and context by moving up and down. She was not seeing me as a person, but she was trying to understand the difference between my face and its background. This is why moving on a seesaw is so fascinating for children.

\section{Object Constancy}

My niece would have experienced object constancy before: mother is not there; she appears in the door and walks in her direction. Mother's face becomes larger until it fills her whole field of vision: is that large object the same object that appeared as a small face peeping through the door? You throw toys out of your box, they bring them back. Repeating experiences like that show constancy in changing objects: different, gradually moving impressions link up to form a single imaginable object. That is why swings and merry-go-rounds are important. Later on you run away from your mother and when you turn round she has become very small and you run back so that she becomes larger again. Mother is not yet understood as a person, but as 'something large and warm', like when three-year-old daughter described her concept of 'mother' after I asked them 'What is a 


\section{Composition Quality}

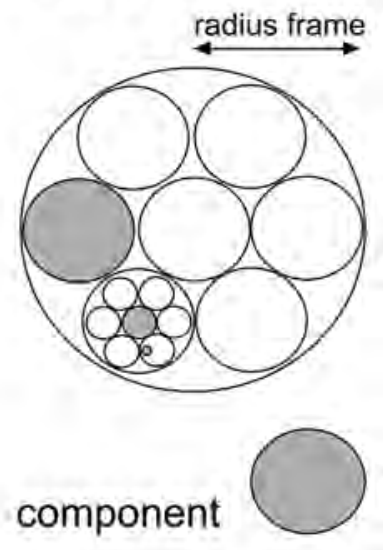

details

\section{Composition quality}

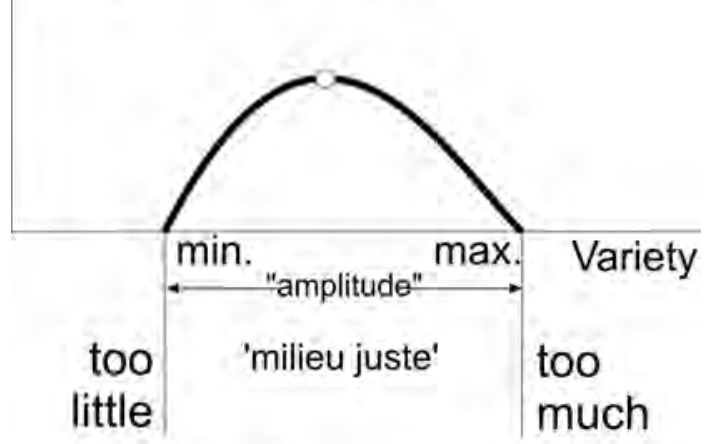

monotony repetition boredom recognition variation chaos surprise overload

Figure 10. Quality as an effect of variety.

mother?' By the same token, dangerous things are 'large and cold'. A car is not dangerous when it is far away, because it is small. The discovery of perspective in art introduces this clarifying movement that we know so well from our childhood as an essential route to understanding.

\section{Components and Details}

At any level of scale, a scene comprises components and details.

To design a recognisable scene, we have to make the larger components externally different from each other, but internally filled with characteristic details recognisably equal to distinguish a particular component from other components with different characteristic details, a paradox of scale. That art is called composition. Figure 9 shows a visual composition, but the inference is also valid for a musical composition with its themes and variations or a theatre production with its acts and dialogues.

\section{Variety}

Contrast

Compound

Proportion

Composition

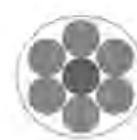

weak strong

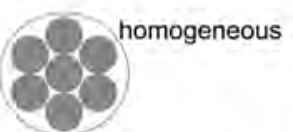

heterogeneous

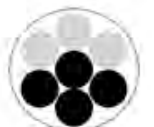

evenly unbalanced

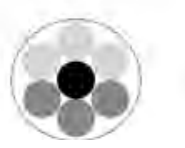

joined fragmented

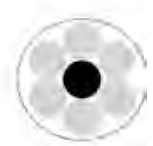

Figure 11. Four Design tools to increase variety. 


\section{Different Components}

The components of an image can be more or less alike. If they are rather different, then the contrast is strong; otherwise, it is weak (Figure 11).

In the range between the most contrasting components within an image, one can distinguish the smallest discernable and the largest discernable contrast. If all the components are similar (non-contrasting, repeating), then we call the composition homogenous, and if they differ we call it heterogeneous. It is possible to see a relationship between compositions of similar components, a relationship that can be either balanced or unbalanced. Even with the same contrast, the same composition and the same relationship, it is still possible to discern variation through composition. Similar components in a composition can be grouped in a more or less compact form. These are the means by which design achieves variety. Any level of scale shows its own composition according to the distance to the object. At any level of scale, components and details have new characteristics of categorisation and orientation.

\section{TENSION}

If a scene operates on several levels of scale, partial compositions become components in the larger composition. The various levels of scale can differ in their degree of heterogeneity. If level 1 is fairly heterogeneous, then level 2, the composition of the level 1 compositions, may be homogeneous to restore the balance between recognition and surprise, equality and difference from Figure 10. We can refer to this as 'tension'. However, if you want to create diversity within any level of scale, you have to differentiate the means of variation for every level of scale to keep the components identifiable by internal homogeneity of another kind, using other variables.

\section{OBSERVABLE VARIABLES OR DIFFERENCES}

To gain an idea of the realities that can be imagined in components and details at different levels of scale, the following question emerges: 'which observable variables differ at every level of scale to distinguish the components and details at that level?' I suppose that a child discovers components and details at an increasing level of scale according to its age (Figure 12).

In your first year of life, the action space $(\mathrm{R}=1 \mathrm{~m})$ has hard and soft, movable and non-movable elements in different colours. In the third year of life, the room $(\mathrm{R}=3 \mathrm{~m})$ has a door, areas in which to play, eat and store, differences in light, material and visibility. These may be legends for designing at that level of scale. Later in life, the house $(\mathrm{R}=10 \mathrm{~m})$ appears to have different levels of accessibility, control, light, noise, temperature, wetness, which are differently suited to playing, personal care and rest. What could we use to distinguish these components?

Then, the garden $(R=30 \mathrm{~m})$ is differently covered, planted and lit by the sun. There are components of the house which extend into the garden or street. You behave differently at the back of the house to the front. There are formal and informal places, hard and soft places, places of recognition and surprise. What is the difference between the lawn and the pavement? Are there in-between areas where one can hesitate about where to go, vague boundaries which do not force you to choose ('in-between realms', as the Dutch architect Aldo Van Eyck named them)?

Your school $(\mathrm{R}=100 \mathrm{~m})$ has spaces where you can sit, run, compete, watch, play and learn. Your village or neighbourhood $(R=300 \mathrm{~m})$ has spaces to buy, 


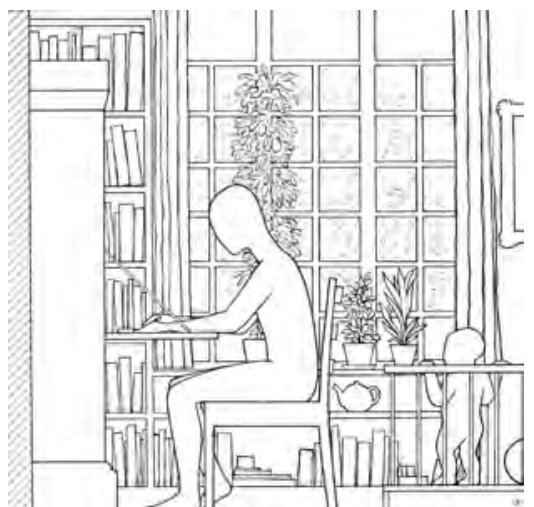

0 year: radius $\mathrm{R}=1 \mathrm{~m}$

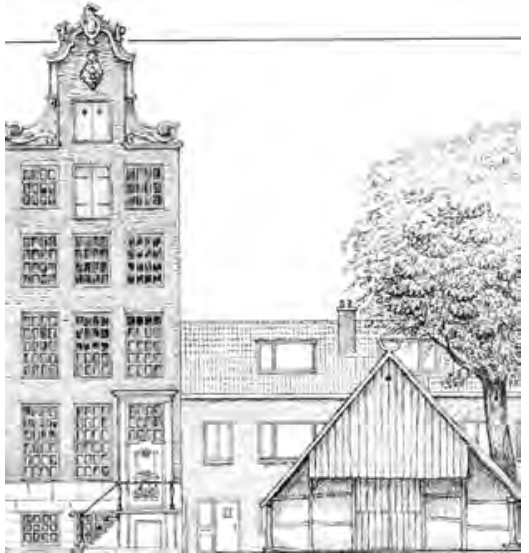

3 years: radius $R=10 \mathrm{~m}$

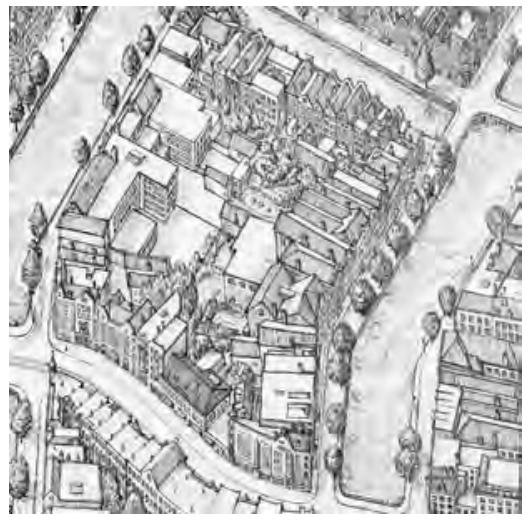

7 years: radius $R=100 \mathrm{~m}$

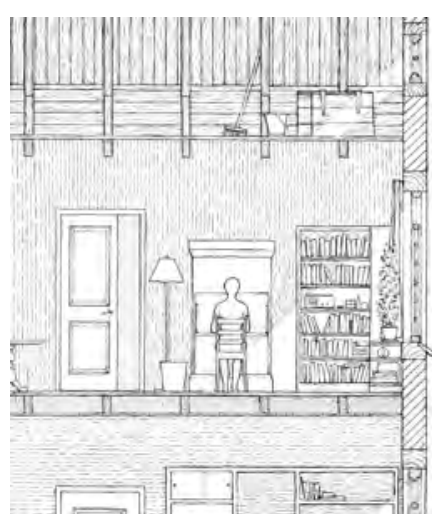

1 year: radius $R=3 m$

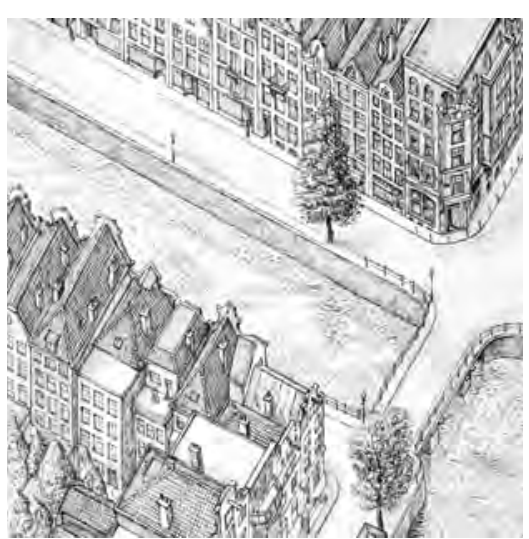

5 years: radius $R=30 \mathrm{~m}$

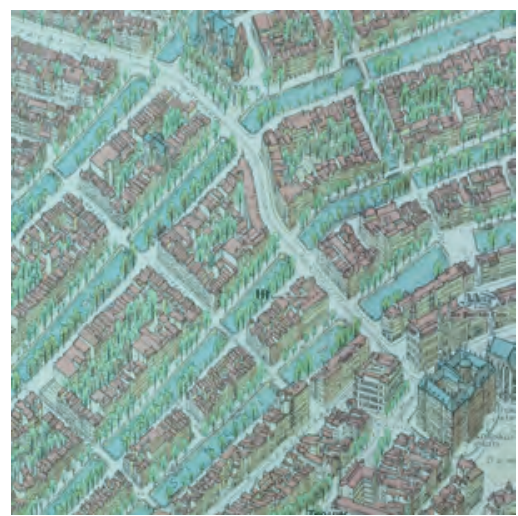

9 years: radius $R=300 \mathrm{~m}$

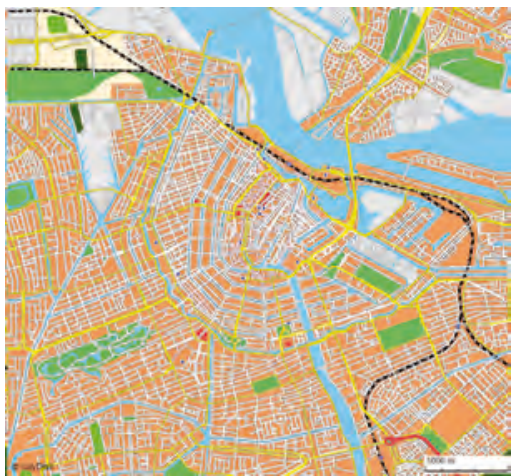

13 years: radius $R=3000 \mathrm{~m}$

Figure 12. Growing awareness by scale.

(Jong, T. M. de; 5 drawings by Jan

Huffener (1978) Milieudifferentiatie;

Een Fundamenteel Onderzoek Thesis,

Delft University of Technology Faculty

11 years: radius $R=1000 \mathrm{~m}$ 
Figure 13. Differences in experience, bounded in legends for design according to the scale of possible application. walk and ride a bike. Your district $(\mathrm{R}=1 \mathrm{~km})$ has spaces in which to live, do business, space for traffic and parks. Your city $(R=3 \mathrm{~km})$ has spaces to meet and retire, atmospheres and cultures to explore.

\section{RESOLUTION}

A field of vision comprises the widest observable radius of reality (frame, expressed as R) and the smallest visible detail (grain, expressed as r). Both alter the composition observed when you approach an object or a scene. The distance from the observed composition is approximately equal to its frame. If the frame of a picture represents a reality of radius $R=10 \mathrm{~m}$ and the grain a radius $r=10 \mathrm{~cm}$, the resolution $r / R$ is $1 \%$. You will call the result a 'drawing'. If frame and grain differ less (say 3\%), it is a rougher 'sketch' which stresses the concept, leaving details and the larger context to the imagination. If they differ more, it could be a more precise blue print $(0.1 \%)$ which leaves fewer details to imagination.

\section{Categories of Design: the Legend as a Vocabulary of Drawing}

At every level of scale, the map you draw may have a different legend, with different categories to imagine (Figure 13).

For example, in a drawing with a frame of $\mathrm{R}=10 \mathrm{~m}$, you can draw tiles in the pavement $(\mathrm{r}=30 \mathrm{~cm})$, the kind of planting, the street furniture and the entries to homes. These are adult categories. Make a sketch to group them

\begin{tabular}{|c|c|c|c|c|c|c|c|c|c|}
\hline $\begin{array}{c}\text { years old } \\
\text { m Radius of frame }\end{array}$ & $\begin{array}{l}0 \\
1 \\
\end{array}$ & $\begin{array}{l}1 \\
3 \\
\end{array}$ & $\begin{array}{c}3 \\
10 \\
\end{array}$ & $\begin{array}{c}5 \\
30 \\
\end{array}$ & $\begin{array}{c}7 \\
100 \\
\end{array}$ & $\begin{array}{r}9 \\
300 \\
\end{array}$ & $\begin{array}{c}11 \\
1000 \\
\end{array}$ & $\begin{array}{c}13 \\
3000 \\
\end{array}$ & learning \\
\hline \multicolumn{10}{|c|}{ differences to experience: } \\
\hline hard-soft & $\mathrm{x}$ & & & & & & & & danger \\
\hline movable I non-movable & $x$ & & & & & & & & operational abilities \\
\hline colour & $x$ & & & & & & & & recognition \\
\hline windows | doors & & $x$ & & & & & & & orientation \\
\hline light I dark & & $x$ & & & & & & & imagination \\
\hline shelter | corners & & $x$ & & & & & & & to escape adult movements \\
\hline function I time & & $x$ & & & & & & & every time having its own place \\
\hline visibility & & $x$ & & & & & & & hide-and-seek \\
\hline accessibility & & & $x$ & & & & & & rules \\
\hline control & & & $x$ & & & & & & other people \\
\hline noise & & & $x$ & & & & & & context \\
\hline temperature & & & $x$ & & & & & & kinds of clothes \\
\hline wetness & & & & $x$ & & & & & hygiene \\
\hline ceiling | shelter & & & & $x$ & & & & & in-betweens to hesitate, to decide \\
\hline plantation & & & & $x$ & & & & & nature \\
\hline sun & & & & $\mathrm{x}$ & & & & & nature \\
\hline formal-informal & & & & $x$ & & & & & different behaviour \\
\hline recognition | surprise & & & & $x$ & & & & & initiative \\
\hline In I compete & & & & & $\mathrm{x}$ & & & & ambition \\
\hline ratch, learn & & & & & $x$ & & & & to learn \\
\hline ossibility to buy & & & & & & $x$ & & & expensiveness \\
\hline ossibility to walk & & & & & & $x$ & & & interest \\
\hline ossibility to ride a bike & & & & & & $x$ & & & ride \\
\hline rban functions & & & & & & & $x$ & & exploration \\
\hline neet | retire & & & & & & & & $x$ & projection I identification \\
\hline tmospheres $\mid$ cultures & & & & & & & & $x$ & identity \\
\hline
\end{tabular}


more roughly using fewer components, comprising child categories. But what do you choose as components and their legend units in other frames? You have to dissect or group them into components suitable for perception at different ages. Figure $\mathbf{1 3}$ gives an overview of variety at each of the levels of scale named previously. You could interpret it as a guiding principle for design: try to change softness every meter, light every three metres and so on. However, light and shadow could be changed successfully on other levels of scale too, for example. The table is only a starting point on which to build.

\section{CHARACTERISTIC, CRUCIAL, CONNECTING AND MARKING DETAILS}

A composition is not only determined by components, but also by details that direct your fixation (focus). Earlier, we mentioned characteristic details, characterising components.

But there are also crucial details, without which the composition would change substantially, connecting details which determine the boundaries and in-between zones and striking or marking details which label the whole scene without being characteristic, crucial or connecting. These are the kinds of details which, as far as I know, verbal language distinguishes.

\section{THREE EXAMPLES OF STYLE AND SCALE}

In each period, and on each level of scale, components and details can be observed which indicate to what extent one can talk about diversity or repetition. In Figure 14, three periods of architectural style, and, for the sake of brevity, the three scale levels linked to them are shown. A tholos for Asklepios in Epidauros, with a radius of 10 metres; Palladio's Villa Rotonda, with a radius of 30 metres; and Berlage's Mercatorplein in the district De Baarsjes (Amsterdam), with a radius of 100 metres.

In the image of the map of the tholos, the components of a radius of about 3 metres appear as the central cella and the components of the peristyllum. Looking at the vertical aspect, the components appear to be an entrance section and the flanking parts of the pillared gallery, and the roof section and foreground are laid out in a similar way. Pillars are the characteristic details of some components. The capitals, triglyphs and other ornaments are connecting details. But what about the top ornament? It is not characteristic of any component, but is it crucial for the composition, marking the temple as a strange body or perhaps connecting it to heaven.

The components of the Villa Rotonda differ more. The middle section is dominant. The special (B) is flanked by the common (A), repeating components following the classical scheme ABA. On the map, a large central section $C$ appears, flanked by similar ABA schemes in which, this time, the peripheral area can be included as the most common component.

In the image of the Mercatorplein, the area is the central component ( $30 \mathrm{~m}$ in radius), flanked by approximately equally large groups of house façades in the corners and along the long sides. The details here consist of façade $(10 \mathrm{~m})$ window and entrance sections $(3 \mathrm{~m})$. The image of a block (of buildings) can also be described within a radius of $100 \mathrm{~m}$. 


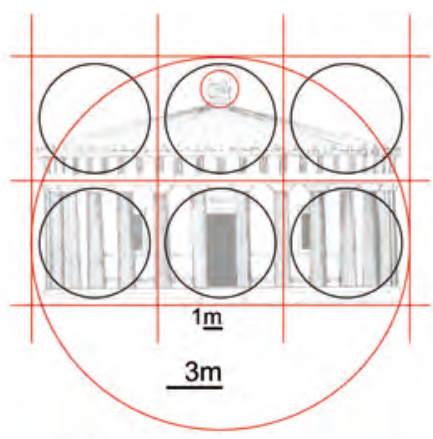

$10 \mathrm{~m}$ radius Image

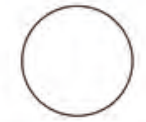

Component

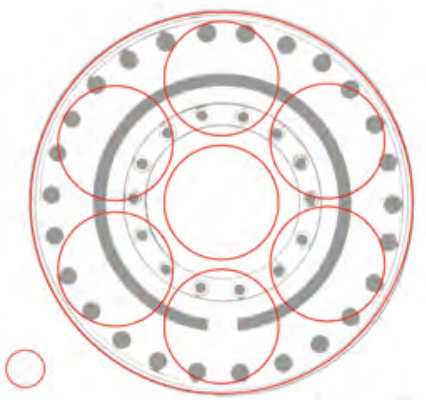

Detail
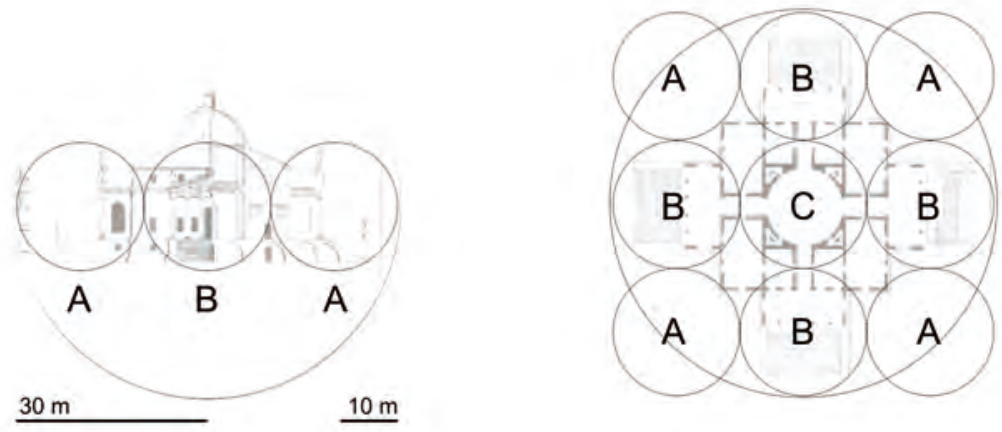

Figure 14. Components and details of images in a radius of 10, 30 and 100 metres.

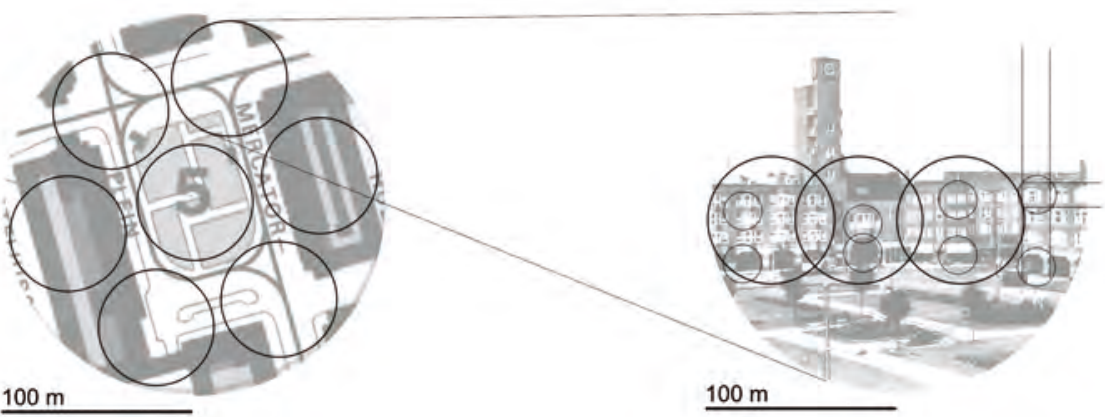

\section{Exploring Possibility, Limitations of Imagination}

The treasury of reality is still not empty for discovery and imagination as our excursion into architecture above may show. Many other categories, different legends for the imagination, can be explored to gain a new impression of the same reality. That realm of possible impressions must be explored through new compositions, changing the engraved boundaries of their components. But the imagination can explore a still larger universe of possibilities. The well-known categories, components and details can be re-arranged into new designs to produce a combinatory explosion of arrangements. However, that does not change the categories that we have inherited through verbal limitations. It can, at most, change their relationships. It will not capture many possible worlds other than those we face. My concern is the verbal limitations that imprison science and society. Any noun or verb is a generalisation of different phenomena in different contexts. Changing contexts generate different meanings for the 
same word. But the category indicated by a word has hidden connotations which we share through language as part of our culture, which is the set of tacit assumptions that we share. Poetry may free our words from some suppositions, but science binds them through definitions. And definitions, in turn, reshape the problem into other words through their suppositions.

Our imagination is limited by the hidden suppositions of inherited categories, which we name with words. You cannot explain what water is to a fish by pointing to something it cannot see. Likewise, we cannot imagine the suppositions that we share as a common culture of apparently self-evident categories. However, creativity requires leaving at least one commonly accepted supposition behind.

Where are the boundaries of the imagination? For many years, I studied the hidden suppositions behind words by comparing them as follows: 'Could you imagine B without A but not the reverse? Then A is a hidden supposition in B.' I compared some 200 words, common in science and technology by asking this question, and published my results in 1992. That required 40,000 comparisons, and resulted in a tree of words that started with one hidden supposition: difference. Even equality, the basis of any form of categorisation and mathematics, appeared to be based on a kind of difference. Equality requires the supposition of two different objects before similarity can be concluded. But difference does not suppose anything: you can see, hear, smell or feel it at any boundary without, necessarily, any enclosing 'objects'. Without any difference, no sense will report you anything. Without a difference, nothing can be observed, chosen or realised. And there are different types of differences, some of which we call 'equality' because we cannot imagine anything less different. But we can always imagine more difference.

And that is the task of art: to make a difference, but to keep it recognisable.

\section{CONCLUSION}

\section{Truth, Probability, Possibility and Imaginability}

Truth has been the main focus of science and philosophy since the time of Thales of Miletus in around 624-545 BC. 'Truth' has been reduced to 'probability' in the last centuries. But reality is more, and possibility is much more. Imagination is less, because it still does not cover the whole of reality, let alone the whole of possibility. In the confusing diversity of reality, empirical science tries only to name and describe regularities. Generalising categories and repeating forms of behaviour between these categories enables us to make predictions, as long as humans behave according to the rationality that is assumed, without freedom of choice. But reality is more than generalisations and predictions based on repetition. Clarifying them leaves an increasing density of particular phenomena to study, which do not fit into named patterns and processes. Moreover, design produces particular phenomena, not copies. Making a difference is the core of art.

\section{Improbable Possibilities}

Research has to be repeatable, but design should not be. If a design is repeated, then it is a copy and, by definition, no longer a design. The improbable images and sounds of designers and composers may be untrue, not referring to an existent reality. But, they are ultimately possible in the sense of technically realisable. Clarifying probability and possibility 
requires different modes of reason and I tried to explain their relationship to arrive at the central concept of this talk: imaginability. What is probable is, by definition, possible, but the reverse is not imaginable. So, there are improbable possibilities you can not predict, because they are not probable. Improbable possibilities have to be designed. And the ecological crisis we face today is forcing us to look for improbable possibilities.

\section{Science as Design}

From the point of view of empirical science, a designer is a liar. A designer does not tell the truth but produces non-existent, improbable images and sounds. A design is also improbable by definition, because if it were probable, it would be a prediction. And predictions based on probabilities belong to the domain of empirical science. Design cannot be empirical science alone, then, because it extends that domain. In fact, the reverse is true: science is itself designed. Science is not hidden in nature, to be found in a field somewhere. It is modelled by humans. Its categories and repeatable behaviours, sometimes modelled in mathematical functions, are designs. If I agree with anything Kant has written, I agree with this: "...dass die Vernunft nur das einsieht, was sie selbst nach ihrem Entwurfe hervorbringt..." - "...that reason only recognises what it realises itself by design ...-" (Kant, 1781, 1976). The power of reason resides in design, not vice versa. So, scientists are a special subset of designers, but not all designers are scientists. Scientists design real or imagined experiments, and experiments require real or imagined instruments. Mathematics is an instrument which has been designed by humans. Instruments have to be designed before science can progress. But those kinds of designs are underexposed in the history of science. Perhaps Hacking (2005) took the first step towards restoring that omission.

\section{Instruments of the Imagination}

Science requires design, then, and not vice versa. Zacharias Jansen, or his father, designed and built the first microscope in Middelburg in 1595, opening up a reality that nobody had imagined before. But is what you see through an instrument reality or imagination, made by man? What does a kaleidoscope show? Can a design open up new realities? The design of the first telescope by said Zacharias Jansen or Johannes Lipperhey, also in Middelburg in 1608, enabled Galileo to see the moons of Venus continuously 'falling' around the planet a year later. It forced humans to imagine more than they could see: an invisible centripetal 'force'. Newton defined force as acceleration times mass, and those are categories that we can imagine. However, Newton never pretended to discover 'truths' as his successors did. He made 'force' imaginable. He simply designed quantitative relationships between designed categories whose behaviour was comparable to that of many realities. Quantities are something that we can imagine. Describing their relationships is known as mathematics, an instrument of thought which is nowadays automated in physical instruments called computers. Are mathematical operations perhaps physical simulations, whether performed in computers or brains?

\section{Condition and Cause}

Archaeologists conclude the historical presence of humans if they find art or instruments which cannot be explained by 'natural' forces. This tacitly supposes 'non-natural' forces as the privilege of humans, who produce artefacts. Since I read Harrison et al. (1964), I have always imagined that the difference between humans and animals is nothing more than the 
Figure 15. Possible futures include probable futures, condition includes cause.
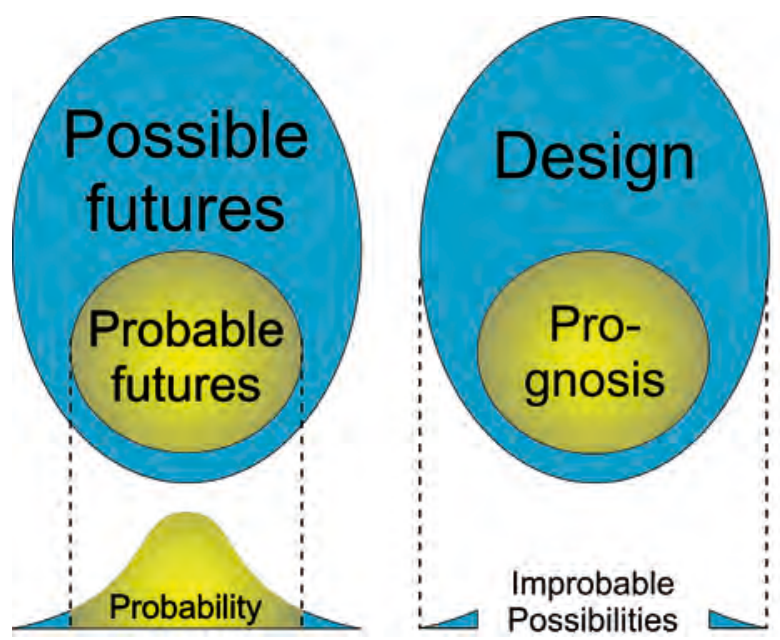

No causes without conditions, context

ability to imagine (or simulate) 'a larger series of actions of which only the first is directly executable'. The first action without direct profit may be to make an instrument (a condition) for further action. But a hammer cannot be used for many further actions, and does not 'cause' a house to exist, it is a condition for making a house, a bed, a table or a chair. It makes them possible and that is a different mode to 'probable'. Imaginable causes make events probable, while conditions make them possible. Shaping conditions is the core of design in all its stages. The first line drawn enables other lines to follow. It does not cause them. Design is not necessarily aims-directed; it opens up new possibilities. It can be means-directed, a form of playing with materials to see what is possible. A house does not cause a household. It makes many households possible. A piece of art does not cause specific emotions, but makes many emotions possible. If the emotion were predicable we might call it kitsch. Any cause is a condition for something to happen, but not every condition is also a cause; that closely resembles the relationship between possibility and probability (Figure 15).

\section{Supposition and Definition}

Words are categories and are full of hidden suppositions buried in a culture which we share (the set of tacit suppositions in communication), of which language is a part. Defining words by using other words does not clarify the suppositions of the underlying (sub-posed) defining words. They are taken for granted as self-evident by inherited culture. The test of 'Could you imagine B without A and not the reverse?' clarifies the order of suppositions that make concepts imaginable. Creativity and art are not part of culture, they produce culture at its rippling surface by removing and adding apparently self-evident suppositions. The test may help us to become aware of hidden suppositions, which can be removed to open up new possibilities. That is the task of art.

\section{REFERENCES}

JONG, T. M. de, VOORDT, D.J.M. van der, eds. (2002) Ways to study and research urban, architectural and technical design, DUP Science, Delft.

PIAGET, J., INHELDER, B. (1947) La representation de l'espace chez l'enfant, Presses Universitaire de France, Paris. 
Alındi: 11.12.2008, Son Metin: 02.04.2010

Anahtar Sözcükler: sanat; tasarım çalışması; görgül araştırma; bağlam duyarlılı̆̆li; yöntem; nedensel düşünce thinking; koşullanmıs düşünce; ayırt etme; imgeleyim.
KANT, I. (1781, 1976) Kritik der reinen Vernunft, Suhrkamp Verlag, Frankfurt am Main.

HACKING, I., $(2005,1983)$ Representing and Intervening. Introductory topics in the philosophy of natural science, Cambridge University Press, New York.

HARRISON, G.A., WEINER, J.S., TANNER, J.M., BARNICOT, N.A. (1964) Human Biology, The Clarendon Press, Oxford.

\section{BİLİMDE SANATIN ROLÜ}

Mimarlık, kentsel tasarım ve ilgili tüm teknik tasarım alanları, bağlamsız ve kategori bağımlı bilimsel genellemeyi reddeden bir bağlam duyarlı yaklaşımla hareket ederler. Tasarım konularını tanımlayan birçok kavram, kategorilerden ve görgül bilimin değişkenlerinden farklıdır. 'Dayanıklı', 'yararlı', 'güzel' gibi birbirleri ile karsılaştırılamayan kategoriler tasarımda biraraya gelmek durumundadır. Bu birleşimler (kombinasyonlar) ‘yarg1 temelli' (statement-based) bilimsel söylemlerle açılanamazlar. Tasarım, sinir bozucu bir biçimde, zamanla açıklığa kavuşturacağı hüküm ve saptamalarla yola çıkar. Görsel imgeler, gözlenen ve niyet edilen mekansal çeşitlilik ile iletişim kurmada kaçınılmazdır. Mekanı cisimleştirmek çelişkileri olanaklı kılar, ancak bu akıldışı bir durum değildir. Tasarım, sözel dile ve klasik mantığa aşkınlaşır. Tasarım, akılcı ama her zaman mantıklı olmayan, kesinlikle öngörülemez bir biçimde imgelemin kaynaklarını kullanır. Sanat düşgücünün (imgelemin) sınırlarını öteler. Düsgücü hem sanatın hem de bilimin temelidir. Sanat, yeni imgelemlere doğru kategorilerin ötesine geçer. Yeni imgelemler, yeni kompozisyonların yapıtaşı niteliğindeki yeni kategorileri bulmak için gereklidir. Tasarım, kendini gerçekleştirilebilir imgelemler ile sınırlar. Bilim kendini 'olasılık' ile sinırlarken tasarımın sınırı 'olabilirliktir.

Bilim beşeri bir tasarımdır, tasarım ise bir sanattır. Bu durumda bilim bir sanat ve beşeri bir yaratımdır. Bu nedenledir ki olasılık, olabilirliği ve olabilirlik de düşgücünü varsayar. İmgelemler ve tasarım araçları sıklıkla bilimsel gelişimin önünü açarlar. Tasarım bilimin bir parçası değilse de, bilim tasarımın bir parçasıdır. Bilim, tasarımın tikel olarak gerçekleştirilmesi durumunda yer alır. Bu, tasarımcıların bilimsel eğitiminin ayrıcalıklı konumuna işaret eder. Bir tasarım kavramı farklı uzmanlardan gelecek önerileri tartıp bütünleştirecektir. Bu öneriler çoğu zaman karşıt ya da çelişkilidir; ama tasarım bundan güçlenerek çıkacaktır. Farklı uzmanlaşmalar, bilimde birbirlerini eleştiremez hale gelen farklı bilim alanlarının takımadaları gibi bir aradalığa yol açmaktadır. Bilim bu yolla kamuoyunda saygınlığını yitirmektedir. Bununla birlikte hala düşgücü için bir talep söz konusudur. Bunu da sanat ve tasarımın rolü sağlayacaktır.

Kamusal imgelem gerçek problemlerin çözümünde başarılı olamamıştır. Bu başarısızlığın nedeni, her bağlamda çözümleri genelleyen kültürün küresel homojenleşmesidir. Gerçek biyo-çeşitliliğin varlığına yönelik farkındalığın azalmasında bu başarısızlığın rolü vardır. Düşgücünün üretebileceği olanakların birleşimsel keşfi konusundaki farkındalık da, bir diğer etken olarak etkindir. Tasarım, olası olmayan olanaklılıkları aramalıdır. Duyularımızın farklı duyusal etkileri birleştirmesi gibi tasarım da karsılaştırılamayan kategorileri ötelemek durumundadır. Bu, kavram inşasının temelidir. Bu durum, sınırlar ötelenirken bünyenizin nesnenin kararlılığı içerisinde hareket ettirme deneyimini bütünler. Yeni nesneler, 
yeni tasarım kompozisyonlarının yapıtaşı ve ayrıntısı haline gelir. Her ölçek düzeyi, eğer kaotik uyumsuzluğa meydan vermiyorsa, ilginç bir gerilime neden olan kendi kompozisyonuna sahiptir.

Bir tasarım çiziminin lejandı, kompozisyonun anahtardır, onun sözcük dağarcığıdır. Kompozisyonun yapıtaşlarını, karakteristiğini, can alıcı, ilişkilendirici ve belirleyici ayrıntılarını belirler. Olabilirliklerimizi keşfetmek, seçim özgürlügü̈müzü geliştirmek için artan bir biçimde kitle iletişim araçlarının klişeleriyle sarmalanan düşgücümüzün sınırlarını kırmak zorundayız. Olası olmayan olabilirlikleri bulmak için düşlemlerimizin gizli kabulleri üzerine çalışmalıyız. Bilim, kendini altkültürlere, değerler dizilerine (paradigmalara) ve jargonlara gizleyen uzmanlıklara böldüğü için, sanat ve tasarım, bilim içinde bir göreve sahiptir.

TAEKE M. DE JONG; BSc; Ph.D.

Graduated in 1976 as an urban engineer at the University of Technology Delft, The Netherlands, and completed his Ph.D. in 1978. After 5 years of practice in urban design, he became an independent advisor. Since 1986 he occupies the chair Technical Ecology And Methods as professor (TEAM: http://team.bk.tudelft.nl/ ). 